\title{
DEVELOPMENT OF ETHNOMATHEMATICS-BASED STUDENT WORKSHEETS ON COURSE OF MATHEMATICS BASIC CONCEPT IN STKIP SINGKAWANG
}

\author{
Evinna Cinda Hendriana ${ }^{1)}$, Buyung ${ }^{2)}$ \\ ${ }^{1)}$ STKIP Singkawang, Singkawang, Indonesia \\ E-mail: evinnacinda@yahoo.com \\ ${ }^{2)}$ STKIP Singkawang, Singkawang, Indonesia \\ E-mail:21.buyung@gmail.com
}

\begin{abstract}
The success of learning mathematics affects the level of mastery of mathematical concepts that elementary school students (SD) must have, as well as prospective elementary school teachers at STKIP Singkawang. One of the factors that support the success of learning mathematics is a model of teaching materials in the form of systematic student worksheets (LKM) and interesting so that it is easy for students to learn individually. The purpose of researching the Development of Ethnomathematics-Based Student Worksheets in the course of Mathematics Basic Concept at STKIP Singkawang is valid, practical, and effective. The method used in this research is the development of the Borg and Gall (1979) 3D model, namely: define, design, and develop. The research subjects were 2 classes, namely the morning class (class A and class B) of the PGSD study program of STKIP Singkawang. Data analysis in this study was carried out through qualitative analysis and quantitative analysis. The quantitative analysis conducted in this study includes validity analysis, practicality analysis, effectiveness analysis. Statistical test using the t-test, Z-test, and ANOVA test. The results showed that the learning tools developed were: (1) valid, after going through the validation process, (2) practical, because there was a good response from students, and (3) the ethnomathematics -based LKM learning tools were effective because the students' ability to understand mathematical concepts reached individual and classical completeness, as well as differences in the ability to understand mathematical concepts in the two classes of device trials.
\end{abstract}

Keywords: LKM; Ethnomathematics; Understanding Concepts

\section{INTRODUCTION}

Teaching basic mathematical concepts must be done properly and correctly so as not to cause further misunderstanding of mathematical concepts, especially for elementary school (SD) students. Therefore, an elementary school teacher is needed who can instill mathematical concepts properly and correctly, so that students can build logical, systematic, consistent, critical, and disciplined reasoning skills through meaningful learning that is developed using culture-based nuances associated with learning. mathematics.

The city of Singkawang is known for its rich diversity of unique cultures, namely Chinese, Dayak, and Malay (TIDAYU) so that by integrating learning with the culture it is hoped that it can provide experiences that can help optimize the learning process for students with different cultural backgrounds.
One of the nuances that can be used to make learning activities more meaningful is ethnomathematics. Mathematics can be defined as the mathematical practice of cultural groups that can be identified and can be considered as the study of mathematical ideas found in every culture (Aqib, 2012). However, in reality, ethnomathematics is still unfamiliar to students in the city of Singkawang when students teach field practice when connecting culture with mathematics so that it has an impact on student understanding of concepts. According to Jacobus (2018), mathematical concepts taught to students are not well embedded in them, so they have an impact on learning outcomes. This requires habituation starting from students who will expect an ethnomathematics-based mathematics learning process.

Teaching basic mathematical concepts must be done properly and correctly so as not to cause further misunderstanding of mathematical concepts, especially for 
elementary school (SD) students. Therefore, an elementary teacher is needed who can make mathematical concepts properly and correctly, so that students can build abilities logically, systematically, consistently, critically. The success of learning mathematics affects the level of mastery of basic mathematical concepts that elementary school students (SD) must have, as well as prospective elementary school teachers at STKIP Singkawang. One of the things that support the success of learning mathematics is a model of teaching materials in the form of systematic student worksheets (LKM) and interesting so that it is easy for students to learn individually, according to Febriani (2016), LKM is a form of teaching material in printed form that can accommodate student activities to foster student stimulus, both physical and mental activity. LKM is designed with the existing culture in Singkawang City, so that MFIs associated with culture can be considered to help students to understand mathematical concepts, especially in the Basic Mathematical Concepts course in SD. According to Prastowo, (2011), culture-based learning is very important for teachers to apply in learning which is useful for increasing the knowledge and understanding of students as well as a medium for cultivating a sense of love for local wisdom in their area.

Based on this matter, it is necessary to develop an ethnomathematics-based LKM in elementary mathematics basic concepts courses for PGSD students at STKIP Singkawang. Through the development of ethnomathematics-based LKM, it is hoped that students will be more active and easier to master the basic concepts of mathematics individually. The research objective was to develop ethnomathematics-based LKM in elementary mathematics basic concepts courses for students that are suitable for use as teaching materials to help master the basic concepts of mathematics properly and correctly and as a supporting facility for the successful learning of Elementary Mathematics Basic Concepts courses at STKIP Singkawang.

\section{Methodology}

The method used in this research is the development of the Borg and Gall (1979) model, with the following stages: Initial information collection, initial planning, product development, initial product testing, product revision, field trial 1, product revision, field trial 2 , product revision, dissemination, and implementation. In this study, only up to product revisions and testing only up to field trials 1 because of the limited time. The research subjects were 2 classes, namely the morning class (class A and class B) of the PGSD STKIP Singkawang study program. The reason for choosing the two classes as the test subjects was because the school had multicultural students so that it was prone to intolerance among students.

\section{A. Data Analysis Technique}

Data analysis in this study was carried out through qualitative analysis and quantitative analysis. Descriptive qualitative data analysis was carried out on the data from the preliminary study results. As for what is meant by qualitative data in this study is only limited to data regarding the description of the ability to understand the concept of students at STKIP Singkawang. Quantitative conducted in this study include: valid, practical, and effective.

\section{B. Data Collection Technique}

The following are some of the techniques needed to collect data in this study, namely: Questionnaires are used to find out data about student responses to the development of ethnomathematics-based LKM. The research instrument test was a test of the ability to understand mathematical concepts.

\section{1) Individual completeness test}

Statistical test formula using equation (1).

$$
t=\frac{z-\mu_{0}}{\frac{S}{\sqrt{n}}}
$$

\section{2) Classical completeness test}

The classical mastery test is used to determine the achievement of students' ability to understand concepts compared to student KKM classically by $75 \%$. The twoparty proposition will be tested using equation (2).

$$
Z=\frac{\frac{\frac{x}{n}-\pi_{0}}{n}}{\sqrt{\frac{\pi_{0\left[1-\pi_{0}\right)}}{n}}}
$$

\section{3) Average difference test}

In the analysis of variance, only one hypothesis is used, namely the two-tailed hypothesis, meaning that this hypothesis wants to find out whether there are differences in the average or not and which are not specific.

\section{RESULTS AND DISCUSSION}

The results of the validation of learning tools by experts showed that each learning device was valid with a good category, with a little revision required. In general, the results of the validation by the experts are shown in Table I.

TABLE I

RESULTS OF VALIDATION OF INSTRUMENT

\begin{tabular}{lccccc}
\hline \multirow{2}{*}{ Device Learning } & \multicolumn{5}{c}{ Validation Average of Each } \\
\cline { 2 - 6 } & $\mathbf{V}_{\mathbf{1}}$ & $\mathbf{V}_{\mathbf{2}}$ & $\mathbf{V}_{\mathbf{3}}$ & Average Criteria \\
\hline $\begin{array}{l}\text { Questionnaire } \\
\begin{array}{l}\text { Response } \\
\text { LKM based on }\end{array}\end{array}$ & 4.25 & 4.00 & 4.25 & 4,16 & Good \\
$\begin{array}{l}\text { Ethnomathematics } \\
\text { TKPKM }\end{array}$ & 4.00 & 4,50 & 4,00 & 4,16 & Good \\
\hline
\end{tabular}

Based on the comments and suggestions from the validator, an evaluation is carried out and is followed up by making revisions to the parts that need to be fixed. After fulfilling the content validity, the TKPKM questions that had been made were then tested in class D (afternoon). This trial is intended to meet the reliability criteria, has a balanced level of difficulty, and the minimum differentiation power is sufficient and will be used as a problem-solving ability test 
that will be given to students in the experimental class and the control class. The recapitulation of the analysis of the test results of the test items on the ability to understand mathematical concepts is presented in Table II.

TABLE II

RECAPITULATION OF TKPKM TRIAL ANALYSIS

\begin{tabular}{|c|c|c|c|c|}
\hline $\begin{array}{l}\text { Question } \\
\text { Number }\end{array}$ & $\begin{array}{c}\text { Validity } \\
\text { Value } \\
\left(\mathbf{r}_{\mathrm{xy}}\right) \\
\end{array}$ & $\begin{array}{c}\text { Difficulty } \\
\text { Level Index }\end{array}$ & $\begin{array}{c}\text { Discriminatory } \\
\text { Power Index }\end{array}$ & $\begin{array}{c}\text { Reliability } \\
\text { Value }\end{array}$ \\
\hline 1 & 0.842 & 0.59 & 0.38 & \multirow{5}{*}{$\begin{array}{c}0.6621 \\
\text { (high) }\end{array}$} \\
\hline 2 & 0.842 & 0.59 & 0.40 & \\
\hline 3 & 0.842 & 0,56 & 0.40 & \\
\hline 4 & 0.751 & 0,69 & 0.34 & \\
\hline 5 & 0.675 & 0,66 & 0.35 & \\
\hline
\end{tabular}

Before testing the device in classes $\mathrm{A}$ and $\mathrm{B}$, we need to find out whether the two classes are homogeneous, meaning that they have the same initial ability or not. Based on the data, it was found that the two classes were homogeneous with a sig value on Levene's Test for Equality of Variances in the Independent Sample Test using SPSS.

The results of the development of ethnomathematicsbased LKM can be said to be practical because after being tested in the experimental class the results were: (1) positive student response, this can be seen from the questionnaire that students gave a positive response of $80.25 \%$ (above $75 \%$ ).

Ethnomathematics-based LKM is said to be effective if after being tested at three schools the results are: (a) the ability of students to understand concepts on conceptual understanding questions on flat shape material to achieve individual and classical learning completeness; and (b) there is a difference in the average ability of students' understanding of mathematical concepts from two different classes.

In this study, the normality test was carried out by SPSS using the Kolmogorov-Smirnov test with a significant level of 5\%. Based on the Normality Test in class A which teaches basic math concepts in elementary school, it is found that the $\operatorname{sig}=0.062=6.2 \%>5 \%$, then $\mathrm{H}_{0}$ is accepted, meaning that the TKPKM results are normally distributed. The normality test in class B who teaches basic mathematical concepts in elementary school shows that the sig $=0.062=6.2 \%>5 \%$ then $\mathrm{H}_{0}$ is accepted, meaning that the TKPKM results are normally distributed (see Table III).

TABLE III

OUTPUT TEST OF NORMALITY

\begin{tabular}{lccr}
\hline & \multicolumn{3}{c}{ Kolmogorov-Smirnov $^{\text {a }}$} \\
\cline { 2 - 4 } & Statistic & Df & \multicolumn{1}{c}{ Sig. } \\
\hline Exsperiment & .151 & 38 & .061 \\
Control & .131 & 38 & .177 \\
\hline
\end{tabular}

From the calculation of the t-test, the value of $t_{\text {count }}=4.92$ in class A. Because $t_{\text {count }}>t_{\text {table }}$ or $4.92>1.69$ this means that $\mathrm{H}_{0}$ is rejected and $\mathrm{H}_{1}$ is accepted. So, the conclusion obtained is that the average score of the Mathematical Concept Understanding Ability Test of students whose learning using ethnomathematics-based LKM has reached $\mathrm{KKM}=70$. From the results of t-test calculations, the value of $t_{\text {count }}=7.97$ in class B. Because $t_{\text {count }}>t_{\text {table }}$ or $7.97>1,69$ this means that $\mathrm{H}_{0}$ is rejected and $\mathrm{H}_{1}$ is accepted. So, the conclusion obtained is that the average score of the Mathematical Concept Understanding Ability Test scores of students whose learning uses ethnomathematics-based LKM learning has reached $\mathrm{KKM}=70$.

Calculation results obtained by class $\mathrm{A}$ arithmetic $Z_{\mathrm{value}}=$ 1.89 . With a real level of $5 \%$ obtained $Z_{\text {table }}=Z_{(0.5-0.05)}=$ $\mathrm{Z}_{0.45}=1.64$. Because $Z_{\text {count }}>Z_{0,5-0,05}$ then $\mathrm{H}_{1}$ is accepted. Thus, it can be concluded that the proportion of students in learning using ethnomathematics-based LKM who achieve individual completion has achieved classical completeness by $75 \%$. Calculation results obtained by class $B$ value of $Z_{\text {count }}=2.05$. With a real level of $5 \%$ obtained $Z_{\text {table }}=Z_{(0.5}$. ${ }_{0.05)}=Z_{0.45}=1.64$. Because $Z_{\text {count }}>Z_{0,5-0,05}$ then $H_{1}$ is accepted. Thus, it can be concluded that the proportion of students in learning using ethnomathematics-based LKM who achieve individual completion has achieved classical completeness by $75 \%$.

This average difference test is used to compare the average ability of students' conceptual understanding in learning using ethnomathematics -based LKM in two different classes. A descriptive table to see the average difference between the two classes taught using ethnomathematics-based LKM can be seen in Table IV.

TABLE IV

DESCRIPTION OF THE AVERAGE DIFFERENCE BETWEEN Two ClASSES

\begin{tabular}{lrrrrrr}
\hline & N & Mean & $\begin{array}{c}\text { Std. } \\
\text { Deviation }\end{array}$ & $\begin{array}{c}\text { Std. } \\
\text { Error }\end{array}$ & Min & Max \\
\hline Class A & 38 & 79.53 & 6.763 & 1.196 & 66 & 92 \\
Class B & 38 & 78.22 & 5.896 & 1.042 & 62 & 90 \\
\hline Total & 76 & 77.88 & 6.417 & .662 & 60 & 92 \\
\hline
\end{tabular}

From Table IV, it appears that the average class A respondent is 79.53 , class $\mathrm{B}$ has an average of 78.22 . Furthermore, to see the test we look at the ANOVA in Table $\mathrm{V}$. Assuming Anova is the variance is the same.

TABLE V

TEST OF HOMOGENEITY OF VARIANCE

\begin{tabular}{lrrrrr}
\hline & $\begin{array}{c}\text { Sum of } \\
\text { Squares }\end{array}$ & df & $\begin{array}{c}\text { Mean } \\
\text { Square }\end{array}$ & F & Sig. \\
\hline Between Groups & 224.909 & 2 & 112.454 & 2.839 & .047 \\
Within Groups & 3604.804 & 91 & 39.613 & & \\
\hline Total & 3829.713 & 93 & & & \\
\hline
\end{tabular}

Furthermore, to see if there is a difference in income between the three school groups. We see the ANOVA table, from that table in the Sig. obtained $P$-value $=0.047$. Thus, at the real level $=0.05$, we reject $\mathrm{H}_{0}$, so the conclusion is that there is a significant difference in the average conceptual understanding ability based on the two classes. Thus it can be concluded that the average ability of understanding concepts based on ethnomathematics is good even though 
there are differences in the average ability of students to understand concepts.

Ethnomathematics-based LKM development is also adapted to the subject, namely the basic concepts of mathematics in elementary school so that it meets the students' needs in developing conceptual understanding skills. According to Deda \& Disnawati (2019), ethnomathematics Student Worksheets using the context of the woven cloth motifs of the Famenanu community can improve learning outcomes in ethnomathematics subjects. In line with this opinion, ethnomathematics-based LKM helps make it easier for students to understand mathematical concepts. In this study, ethnomathematics-based LKM also showed good results on student learning outcomes in elementary mathematics basic concepts courses.

Assessment of student outcomes during the learning process includes aspects of cognitive aspects and observation sheets. The cognitive aspects are obtained from assignments, quizzes, and post-tests (tests of the ability to understand mathematical concepts). The process of developing ethnomathematics-based ability test questions consists of 3 questions. The questions developed can be categorized as valid qualitatively and practically. Valid is reflected in the results of the validator's assessment, where almost all validators state both constructs (developing mathematical literacy skills, rich in concepts) and language (according to the EYD, the questions are not convoluted, the questions do not contain multiple interpretations, the question and answer boundaries are clear).

The development of learning devices has gone through the process according to the device development procedures specified in this study, namely the modification of the Borg and Gall (1979) Model. Based on the results of the validation, the learning device has been declared valid, but revisions are still needed. The revision of ethnomathematicsbased LKM is carried out mainly on the exposure of material must be accompanied by concepts according to the culture used in this study, as well as exercises to develop students' conceptual understanding skills.

Ethnomathematics-based LKM learning devices are said to be practical if after being tested in the experimental class they get positive student responses. Student response data to ethnomathematics-based LKMs were collected using the student response questionnaire sheet instrument provided by the researcher. From the results of filling out the student response questionnaire, it was found that students gave a positive response. Behavior can be in the form of a change in the individual, either visible or hidden (Simanjuntak \& Imelda, 2018). A pleasant feeling will result in students having a positive response to taking part in learning so that students are more confident. The response is a response or feeling of students after participating in learning.

Learning is said to be effective if after being tested it gets the following results: (a) students' ability to understand concepts on geometrical material problems, especially flatsystem shapes, achieves individual and classical completeness; (b) the ability to understand the concept of students in the test class of the Ethnomathematics-Based
LKM device there is no difference between the two trial classes.

The instruments used in testing the effectiveness of the learning tools were (1) TKPKM which had been compiled using indicators of the ability to understand mathematical concepts. The results of the test of students' ability to understand mathematical concepts are obtained, analyzed, and used to determine the effectiveness of the learning tools being developed.

Based on the results of the TKPKM completeness test, the group of students with ethnomathematics-based LKMs achieved the minimum completeness criteria (KKM) of 70 . Meanwhile, based on the classical completeness test, it showed that the group of students with ethnomathematicsbased LKM achieved classical completeness. This shows that students in the ethnomathematics-based LKM class achieve completeness in learning KKM.

Learning using ethnomathematics-based LKM has brought students to achieve learning completeness, therefore learning using ethnomathematics-based learning can be used to train students' ability to understand mathematical concepts. This is in line with Disnawati \& Nahak (2019), the developed worksheets can be indicated from the learning outcomes of students both in writing and orally during the field test. More than $80 \%$ of students achieved the completeness criteria and based on questionnaires and interviews it was found that students were very fond and motivated to learn mathematics using ethnomathematicsbased worksheets.

Based on the research results, during the learning process students are allowed to construct their own experiences in solving problems of understanding mathematical concepts. Learning using ethnomathematics-based LKM provides a meaningful learning process for students. This causes the ability of student concept understanding to increase and the TKPKM results of students have exceeded the value of the research target. The number of students in the trial class who completed the KKM had also reached classical mastery. This result is in line with the research of Setiana and Ayuningtyas (2018) that the ethnomathematics-based Student Activity Sheet (LKS) developed is effective because the percentage of classical completeness on the mathematics test results has exceeded $75 \%$.

Learning using ethnomathematics-based LKM emphasizes the use of real problems and questions that are following the indicators of understanding concepts related to culture in Singkawang City to support students' ability to understand concepts. Emphasis on the use of cultural problems following the 2013 curriculum so that learning is more meaningful. The results of this study are in line with research by Khalimah et al. (2017) that ethnomathematicsbased worksheets in mathematics learning given will feel meaningful for students and can develop their ideas.

Based on the results of the analysis, it was concluded that the average value of the test scores for the ability to understand the concepts of class A and class B of the PGSD STKIP Singkawang study program was different in the flatsided building material. The results of data processing using 
the mean difference test indicate that the device trial class has an average value of the ability to understand different concepts. The results obtained by class $\mathrm{A}$ are higher because when the learning process student activities are more enthusiastic. Meanwhile, class B student enthusiasm also looks very good or enthusiastic. If it is concluded that learning using ethnomathematics-based LKM has a good impact on the test results of the ability to understand mathematical concepts. the use of ethnomathematics-based worksheets in Hindu ceremonial facilities (Banten Upakara) in Bali which is related to the concepts of flat wakes in everyday life makes learning more meaningful (Paramartha, Suharta, \& Parwati, 2020).

The development of learning tools using ethnomathematics-based LKM by supporting the ability to understand mathematical concepts is very likely to take place because learning can take place by implementing online learning. The development of ethnomathematicsbased LKM learning tools by supporting the ability of students to understand mathematical concepts in the trial class creates a learning process and knowledge transfer that is more optimal than that, so it is only natural that the ability of students to understand mathematical concepts in the device testing class say good. Oktarina, Luthfiana, \& Refianti (2019) stated that the ethnomathematics-oriented student worksheet based on the guided discovery that was developed was declared valid, practical, and potential in improving student learning outcomes on flat-sided building materials.

\section{CONCLUSIONS}

Development of learning tools. which has been modified, produces learning tools using the ethnomathematics-based Student Work Institute (LKM) that are valid and practical, and are effective. The development of ethnomathematicsbased LKM learning materials for students' flat-sided shapes resulted from valid learning tools. Ethnomathematics-based LKM learning devices on the material of student's flat-sided wake which are developed practically Learning tools developed are practical because after being tried out, the students give a positive response. Implementation of ethnomathematics-based LKM learning is effective. The learning is said to be effective because after being tested, the results are: (1) the average ability of students' concept understanding using ethnomathematics-based LKM has reached individual and classical completeness at the KKM limit $=75$ and the classical completeness limit is $75 \%$; (2) the ability to understand mathematical concepts in the learning class using ethnomathematics-based LKM has no difference

\section{ACKNOWLEDGMENT}

Thanks to STKIP Singkawang for facilitating this research to be carried out, thanks to the Directorate of Research and Community Service Directorate General of Research and Technology Strengthening and Development of the Ministry of Research, Technology and Higher Education by the 2020 Budget Year Research Contract with contract number 398 / L11 / KM / 2020.

\section{REFERENCES}

Aqib, Z. (2012). Pendidikan karakter di sekolah membangun karakter dan kepribadian anak. Bandung: Yrama Widya.

Bodie, Z., A, Kane., and A, J. Marcus. (2002). Investments. Boston: McGraw Hill.

Borg, Walter R., Gall, Meredith D. (1979). Educational Research. New York: Longman

Brav, A., \& Heaton, J.B. (2002). Competing Theories of Financial Anomalies. Review of Financial Studies 15, 575-606.

Campbell, R. H., Lins, K. V., \& Roper, A. H. (2004). The Effect of Capital Structure When Expected Agency Costs are Extreme. Journal of Financial Economics, 445-460.

Deda, Y. N., \& Disnawati, H. (2019). Pengembangan Lembar Kerja Mahasiswa (LKM) Etnomatematika Menggunakan Konteks Motif Kain Tenun Timor. Jurnal Karya Pendidikan Matematika, 6(2), 20-26.

Disnawati, H., \& Nahak, S. (2019). Pengembangan Lembar Kerja Siswa Berbasis Etnomatematika Tenun Timor pada Materi Pola Bilangan. Jurnal Elemen, 5(1), 64-79.

Febriani, M. (2016). Pemanfaatan lembar kerja mahasiswa untuk meningkatkan keaktifan mahasiswa. Jurnal pendidikan bahasa dan sastra, 16(1), 203-212.

Jacobus, A. 2018. Penggunaan Media 'Bungnge Tallo' Untuk Meningkatkan Pembelajaran Bilangan Kubik Pada Siswa Sekolah Dasar. Jurnal Dikdaktika Pendidikan Dasar, 2(2).

Khalimah, N., Farin, K. I., Nikmah, M., Ni'mah, K., \& Jatmiko, J. (2017). Budaya Kediri dalam Pembelajaran Matematika (Pengembangan Lembar Kegiatan Siswa (LKS) Berbasis Etnomatematika Melalui Pendekatan Saintifik). JIPMat, 2(1).

Oktarina, A., Luthfiana, M., \& Refianti, R. (2019). Pengembangan Lembar Kerja Siswa (LKS) Etnomatematika Berbasis Penemuan Terbimbing pada Materi Bangun Ruang Sisi Datar. Jurnal Pendidikan Matematika: Judika Education, 2(2), 91-101.

Paramartha, I. G. L., Suharta, I. G. P., \& Parwati, N. N. (2020). Penerapan Lembar Kerja Siswa (LKS) Matematika Berbasis Etnomatematika Untuk Meningkatkan Kemampuan Pemecahan Masalah Dan Membangun Karakter Positif Siswa. Journal for Lesson and Learning Studies, 3(1), 30-40.

Prastowo, A. (2011). Panduan kratif membuat bahan ajar inovatif. Yogyakarta: Diva Press.

Setiana, D. S., \& Ayuningtyas, A. D. (2018). Pengembangan Lembar Kegiatan Siswa (LKS) matematika berbasis Etnomatematika Kraton Yogyakarta. Science Tech: Jurnal Ilmiah Ilmu Pengetahuan dan Teknologi, 4(2), 67-74. 
Simanjuntak, S. D., \& Imelda, I. (2018). Respon Siswa Terhadap Pembelajaran Matematika Realistik Dengan Konteks Budaya Batak Toba. MES:
Journal of Mathematics Education and Science, 4(1), 81-88. 